\title{
Preliminary indications for diverging heat and drought sensitivities in Norway spruce and Scots pine in Central Europe
}

\author{
Norbert Kunert ${ }^{(1-2)}$
}

\section{Introduction}

Climate-change induced forest mortality is currently a rapidly emerging trend (Allen et al. 2010). This means that many forests have lost their ability to sustain the global biogeochemical cycle or their function in providing vital habitat, and valuable ecosystem services for human communities (Cobb et al. 2017). A good understanding of the drivers, general patterns, and severity strategies to reduce economic and cultural consequence (Allen et al. 2010). In Europe, Norway spruce and Scots pine have been the two most important timber species for the forestry sector over centuries (for historic background see Hartig 1791, Stromer Von Reichenbach 1968). Especially, those two economically very important conifer species have been massively affected by accelerated tree mortality in recent years across Europe (Allen et al. 2010). In the past, the main cause of mortality in Norway spruce was wind disturbance with of changes can help to apply mitigation

\begin{abstract}
Massive and increasing tree mortality is currently observed in the two conifer species Norway spruce and Scots pine in Central Europe. Consecutive dry years are made responsible for this phenomenon. Leaf trait measurements, in specific leaf osmotic potential $\left(\pi_{\mathrm{osm}}\right)$ and leaf water potential at turgor loss $\left(\pi_{\mathrm{t} t \mathrm{p}}\right)$, indicate that the underlying mechanisms for tree mortality are most likely different between the two species. $\pi_{t \mid p}$ of spruce was highly negative, revealing a potentially high drought tolerance of the species. $\pi_{\text {tlp }}$ of Scots pine was less negative, suggesting a higher susceptibility to drought stress. I conclude that the mortality of Norway spruce might be caused by rising temperatures and that the summer temperatures in the past years were beyond the species thermal tolerance threshold. Overall, I want to highlight and enhance the discussion that the search for suitable species for a climate change adapted forest should go in both directions, i.e., species should be chosen to make the forest fit for both increasing drought and heat stress.
\end{abstract}

Keywords: Tree Mortality, Water Stress, Heat Stress, Physiological Limitations, Conifers consecutive disastrous bark beetle outbreaks (Eriksson et al. 2007). The increasing frequency of summer drought and heatwaves has replaced wind disturbance as the main cause of Norway spruce mortality (Hentschel et al. 2014). In Central Europe, the massive mortality of Scots pine is a relatively new phenomenon in many areas and came for many forest managers and decision-makers almost unexpected (Kunert 2019), especially as Scots pine has been thought to be relatively drought tolerant. Hence, drivers and mechanisms causing tree mortality are not always clear. This study presents the leaf osmotic potential $\left(\pi_{\text {osm }}\right)$ as a tree physiological measure that is directly related to a species drought tolerance. $\pi_{\text {osm }}$ can be translated into the leaf water potential at turgor loss (turgor loss point, $\pi_{\mathrm{tp}}$ ) and represents the permanent wilting point (Bartlett et al. 2012). The aim of this study was to verify if water limitation explains the accelerated mortality in Norway spruce and Scots pine
(1) Conservation Ecology Center, Smithsonian Conservation Biology Institute, Front Royal, VA (USA); (2) Center for Tropical Forest Science - Forest Global Earth Observatory, Smithsonian Tropical Research Institute, Panama (Republic of Panama)

@ Norbert Kunert (kunertn@si.edu)

Received: Aug 18, 2019 - Accepted: Dec 11, 2019

Citation: Kunert N (2020). Preliminary indications for diverging heat and drought sensitivities in Norway spruce and Scots pine in Central Europe. iForest 13: 89-91. - doi:

10.3832/ifor3216-012 [online 2020-03-01]

Communicated by: Tamir Klein from a leaf hydraulic perspective and to present a comparison to the regional species pool.

\section{Methods}

\section{Study area}

The collection of the plant material took place in the surroundings of Ammerndorf in the rural district of Fürth in Middle Frankonia, Germany $\left(49^{\circ} 24^{\prime} 36.0^{\prime \prime} \mathrm{N}, 10^{\circ}\right.$ $\left.49^{\prime} 39.3^{\prime \prime} \mathrm{E}\right)$. The forest management history of the district is influenced strongly by Peter Stromer, who initiated a reforestation approach in the year 1368, turning the formerly depleted mixed-species forests (probably Scots pine, birch, and oak) into pure stands of Scots pine (Pinus sylvestris L. - Stromer Von Reichenbach 1968). The area is characterized by a very patchy forest distribution. Approximately $30 \%$ of the area is currently stocked with forest and the rest is used for agriculture. The main tree species cultivated in the area are Scots pine, followed by Norway spruce (Picea abies Karst.). The two conifer species make up $80 \%$ of the forest area and the other $20 \%$ by broadleaved species, with European oak (Quercus robur L.) being the most important species and the invasive black cherry (Prunus serotina Ehrh.) rapidly taking over the understory. The area has experienced various dramatic and cascading die-off events in the last two years following three very dry summers and heatwaves in 2015, 2016 and 2019 (Klemmt et al. 2018). Bark beetle outbreaks have killed about 30\% of the spruce trees and a complex combination of fungi are accelerating the mortality of pine (Kunert 2019). In some stands, all 
Tab. 1 - List of native woody species sampled during the study.

\begin{tabular}{|l|}
\hline Species name \\
\hline Abies alba \\
\hline Acer campestre \\
\hline Acer platanoides \\
\hline Acer pseudoplatanus \\
\hline Alnus glutinosa \\
\hline Betula pendula \\
\hline Caprinus betulus \\
\hline Cornus sanguinea \\
\hline Corylus avellana \\
\hline Crataegus monognae \\
\hline Euyonimos europea \\
\hline Fagus sylvatica \\
\hline Frangula alnus \\
\hline Fraxinus excelsior \\
\hline Ilex aquifolium \\
\hline Larix decidua \\
\hline Picea abies \\
\hline Pinus sylvestris \\
\hline Populus tremula \\
\hline Prunus avium \\
\hline Prunus spinosa \\
\hline Quercus patrea \\
\hline Quercus robur \\
\hline Salix alba \\
\hline Salix caprea \\
\hline Sambucus nigra \\
\hline Sambucus racemosa \\
\hline Sorbus aucoparia \\
\hline Taxus bacata \\
\hline Tilia cordata \\
\hline Tilia platyphyllos \\
\hline Ulmus glabra \\
\hline
\end{tabular}

pine trees have died, which means that only $20 \%$ of the stand is stocked with mainly oaks. To compare the potential drought tolerance of spruce and pine with the local tree community, botanical samples were collected for 32 woody species native to the area (Tab. 1). I assume that this species pool ( $25^{\text {th }}$ to $75^{\text {th }}$ percentile, see box plots in the figure) would reflect well the historic drought adaptation of the local woody vegetation.

\section{Determination of the turgor loss point via osmometry}

The water potential at turgor loss point $\left(\pi_{\mathrm{tp}}\right)$ was estimated by measuring the leaf osmotic potential at full hydration $\left(\pi_{\mathrm{osm}}\right)$ with a vapor pressure osmometer (VAPRO $5520^{\oplus}$, Wescor, Logan, UT, USA - Bartlett et al. 2012). Three tree individuals per species were sampled. One sun-exposed branch from each individual was collected during the growing season between the $7^{\text {th }}$ and the $12^{\text {th }}$ of July 2019. After cutting the branches from the trees, they were placed in humid and opaque plastic bags and brought to the laboratory as fast as possible. In the laboratory, the branches were cut again underwater at least two nodes distal to the original cut and placed in buckets with water, covered with plastic bags to let rehydrate overnight. The next day, two leaf samples were taken per individual. All collected samples were processed within $24 \mathrm{~h}$ after collection. For broadleaved species, fully expanded leaves per branch of broad were collected and a disc was cut

Fig. 1 - Mean values and standard deviation of the $(A)$

water potential at turgor loss $\left(\pi_{\mathrm{tlp}}\right)$; and (B) osmotic leaf water potential $\left(\pi_{\text {osm }}\right)$ of the target species and the most economically important broadleaved species in Central Europe. The box plot presents $\pi_{\mathrm{tlp}}$ and $\pi_{\text {osm }}$ of 32 woody species collected in the study area. Three individual ( $\mathrm{n}$ =3) for each species were sampled to measure $\pi_{\text {tlp }}$ and $\pi_{\text {osm }}$. Values for the box plot are based on the mean values of the 32 species. The upper and lower limits of the box plots represent estimates of the $75^{\text {th }}$ and $25^{\text {th }}$ percentiles.

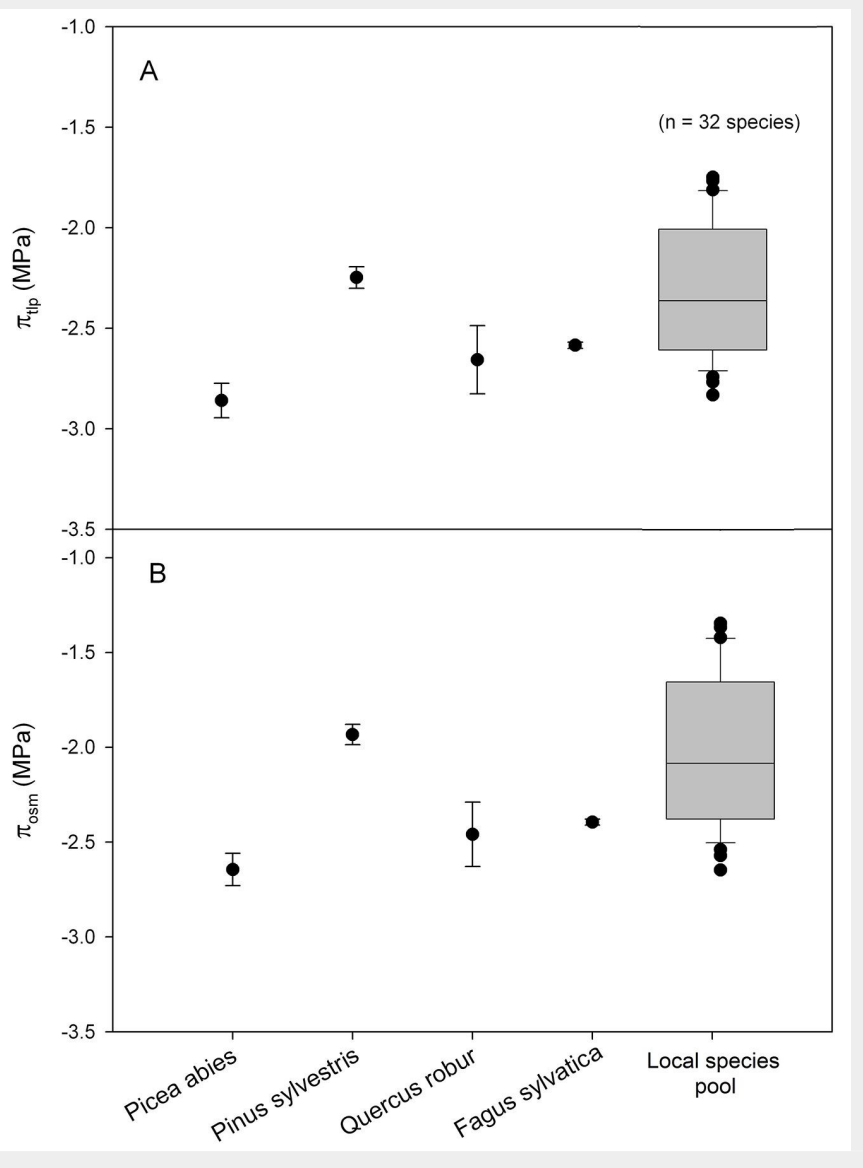

out per sample with a 4-mm-diameter cork borer. From the rehydrated branch of the conifers, a couple of needles were used and aligned next to each other to form a larger area, so that a disc could be cut out with similar size to the broad-leaved species. The discs were wrapped in aluminum foil and submerged in liquid nitrogen $\left(\mathrm{LN}_{2}\right)$ for at least 2 minutes (Bartlett et al. 2012). The standard $10 \mu \mathrm{L}$ chamber well of the osmometer was used for the measurements. Before putting the discs into the chamber of the osmometer, the discs were punctured with a dissection needle for about 10 to 15 times to improve evaporation through the cuticle and to reduce equilibration time (Kikuta \& Richter 1992). The osmometer was running in the auto-repeat mode and all measurements were recorded until the equilibrium was indicated by an increase between measurements of less than $0.01 \mathrm{MPa}$ (approximately 5 osmometer readings). The osmotic potential at full hydration $\left(\pi_{\mathrm{osm}}\right)$ was calculated from the solute concentration value $c_{0}$ (in $\mathrm{mmol} \mathrm{kg}^{-1}$ ) given by the osmometer, using the following equation (eqn. 1):

$$
\pi_{\text {osm }}=\frac{R \cdot T}{1000} c_{0}
$$

where $R$ is the ideal gas constant, and T, the temperature in degrees Kelvin (here 25 $\left.{ }^{\circ} \mathrm{C}\right)$. Leaf water potential at turgor loss $\left(\pi_{\mathrm{tp}}\right)$ was calculated $\pi_{\text {osm }}$ using the calibration equation established by Bartlett et al. (2012 - eqn. 2):

$$
\pi_{t l p}=0.832 \pi_{\text {osm }}-0.631
$$

\section{Results}

The main results of this study are summarized in Fig. 1.

The $75^{\text {th }}$ and $25^{\text {th }}$ percentile of the species pool were -2.01 and $-2.60 \mathrm{MPa}$ for $\pi_{\text {tlp }}$ and -1.66 and $-2.37 \mathrm{MPa}$ for $\pi_{\text {osm. }}$. Mean $\pi_{\text {tip }}$ lies at $-2.33 \pm 0.33 \mathrm{MPa}$ and mean $\pi_{\text {osm }}$ at $-2.04 \pm$ $0.40 \mathrm{MPa}$. The two target species had a $\pi_{\text {tlp }}$ of $-2.83 \pm 0.085 \mathrm{MPa}$ and $-2.24 \pm 0.054 \mathrm{MPa}$ (Picea abies and Pinus sylvestris, respectively). Their $\pi_{\text {osm }}$ was at $-2.64 \pm 0.10 \mathrm{MPa}$ and $-1.93 \pm 0.065 \mathrm{MPa}$. Common broadleaved species like Quercus robur and Fagus sylvatica had a $\pi_{\text {tlp }}$ of $-2.68 \pm 0.17 \mathrm{MPa}$ and $-2.62 \pm 0.02 \mathrm{MPa}$, respectively. $\pi_{\text {osm }}$ was at $-2.46 \pm 0.20 \mathrm{MPa}$ and $-2.39 \pm 0.02 \mathrm{MPa}$.

\section{Discussion}

$\pi_{\text {tlp }}$ measurements revealed that Norway spruce loses its turgor at a more negative leaf water potential. In contrary, Scots pine loses its turgor earlier with less negative leaf water potential. This means that Scots pine reaches its permanent wilting point earlier under water limitation than Norway spruce (Bartlett et al. 2012). This approach disregards possible differences in rooting depth of the two species and water accessibility during drought; however, various studies have shown that both species have 
most of their fine roots in the same soil layer and do not access layers deeper than $50 \mathrm{~cm}$ with a significantly different amount of fine roots (Jackson et al. 1996, Finér et al. 2007, Helmisaari et al. 2007). Hence, it can be assumed that both species are accessing water resources at the same soil layer and that from leaf hydraulic point of view Norway spruce is much more drought tolerant than Scots pine. Despite possible differences in rooting and soil water uptake pattern, Norway spruce has even lower $\pi_{\text {osm }}$ and $\pi_{\text {tlp }}$ than the $25^{\text {th }}$ percentile of the species in the area. This means that Norway spruce might be potentially more drought tolerant than most other species, even more, tolerant to drought than oak and beech trees (Fig. 1). I conclude that the main underlying mechanism of accelerating Norway spruce mortality does not lie in water stress but rather in heat stress caused by heatwaves. In the last years a significantly increasing number of heatwaves, defined as at least three consecutive days with a maximum daily air temperature of $>30^{\circ} \mathrm{C}$, has been observed in Central Europe (Tomczyk \& Bednorz 2019). Norway spruce has been planted in many lowland areas near or at the edge of its thermal tolerance. Those temperature regimes during the heat waves are most likely reaching the thermal tolerance threshold (Curtis et al. 2014,Cochard 2019) of the species leading to lethal heating of leaves (O'Sullivan et al. 2017). As higher altitudes are affected by heatwaves too, the thermal tolerance threshold could explain mortality in higher and cooler environments. To my knowledge there is no study on the thermal tolerance threshold of Norway spruce to support my speculation; most studies focus rather on the freezing tolerance of these species (e.g., combination of freezing and drought tolerance Blödner et al. 2005). Similar mechanisms of tree mortality concerning heat might apply to the currently observed wilting of beech trees all over central Europe. From the leaf hydraulic perspective, European beech and oak have similar $\pi_{\text {tlp }}$; however, species distributional range of European oak reaches much further south with historically higher maximum temperatures (Southern Turkey and Northern Iraq, an area with scorching high temperatures to quite high altitudes). The principle mechanism of mortality in Scots pine might be defined by drought stress followed by pathogen outbreaks such as the Diplodia tip blight (Klemmt et al. 2018), often combined with the cauliflower fungus (Sparassis crispa), a cellulose digesting species significantly reducing water uptake in the trunk (Kunert 2019).

\section{Conclusion}

Mortality in the two most economically important conifer species in Central Europe might be explained by two different mech- anisms. Norway spruce might be more affected by being pushed to its thermal tolerance threshold, whereas Scots pine suffers from water limitation. However, both drought and heat are threatening forest ecosystems with progressing climate change and will be the most pressing task to be tackled by forest managers in the coming years. Therefore, the search for suitable species must account for the thermal tolerance threshold and a species' drought tolerance.

\section{Acknowledgements}

I would like to thank Jürgen Bauhus to assure funding for the consumables used in this study. I also thank Alida Mercado Cardenas for language editing. Finally, I am deeply indebted to two anonymous reviewers who helped to improve essentially the manuscript.

\section{References}

Allen CD, Macalady AK, Chenchouni H, Bachelet $D$, McDowell N, Vennetier M, Kitzberger T, Rigling A, Breshears DD, Hogg EH, Gonzalez P, Fensham R, Zhang Z, Castro J, Demidova N, Lim $\mathrm{JH}$, Allard G, Running SW, Semerci A, Cobb N (2010). A global overview of drought and heatinduced tree mortality reveals emerging climate change risks for forests. Forest Ecology and Management 259: 660-684. - doi: 10.1016/j. forec0.2009.09.001

Bartlett MK, Scoffoni C, Ardy R, Zhang Y, Sun S, Cao K, Sack L (2012). Rapid determination of comparative drought tolerance traits: using an osmometer to predict turgor loss point. Methods in Ecology and Evolution 3: 880-888. - doi: 10.1111/j.2041-210X.2012.00230.X

Blödner C, Skroppa T, Johnsen O, Polle A (2005). Freezing tolerance in two Norway spruce (Picea abies [L.] Karst.) progenies is physiologically correlated with drought tolerance. Journal of Plant Physiology 162: 549-558. - doi: 10.1016/j.jplph.2004.09.005

Cobb RC, Ruthrof KX, Breshears DD, Lloret F, Aakala T, Adams HD, Anderegg WRL, Ewers BE, Galiano L, Grünzweig JM, Hartmann H, Huang $\mathrm{CY}$, Klein $\mathrm{T}$, Kunert $\mathrm{N}$, Kitzberger $\mathrm{T}$, Landhäusser SM, Levick S, Preisler $Y$, Suarez ML, Trotsiuk V, Zeppel MJB (2017). Ecosystem dynamics and management after forest die-off: a global synthesis with conceptual state-andtransition models. Ecosphere 8 (12): e02034. doi: $10.1002 /$ ecs2.2034

Cochard H (2019). A new mechanism for tree mortality due to drought and heatwaves. bioRxiv: 531632 . - doi: 10.1101/531632

Curtis EM, Knight CA, Petrou K, Leigh A (2014). A comparative analysis of photosynthetic recovery from thermal stress: a desert plant case study. Oecologia 175: 1051-1061. - doi: 10.1007/s 00442-014-2988-5

Eriksson M, Neuvonen S, Roininen H (2007). Retention of wind-felled trees and the risk of consequential tree mortality by the European spruce bark beetle Ips typographus in Finland. Scandinavian Journal of Forest Research 22:
516-523. - doi: 10.1080/02827580701800466 Finér L, Helmisaari HS, Lõhmus K, Majdi H, Brunner I, Borja I, Eldhuset T, Godbold D, Grebenc T, Konôpka B, Kraigher H, Möttönen MR, Ohashi M, Oleksyn J, Ostonen I, Uri V, Vanguelova E (2007). Variation in fine root biomass of three European tree species: Beech (Fagus sylvatica L.), Norway spruce (Picea abies L. Karst.), and Scots pine (Pinus sylvestris L.). Plant Biosystems 141: 394-405. - doi: 10.1080/11263500701625897 Hartig GL (1791). Anweisung zur Holzzucht für Förster [Instructions for tree breeding for foresters]. Neue akademische Buchhandlung, Marburg, Germany, pp. 143. [in German]

Helmisaari HS, Derome J, Nöjd P, Kukkola M (2007). Fine root biomass in relation to site and stand characteristics in Norway spruce and Scots pine stands. Tree Physiology 27: 14931504. - doi: 10.1093/treephys/27.10.1493

Hentschel R, Rosner S, Kayler ZE, Andreassen K, Borja I, Solberg S, Tveito OT, Priesack E, Gessler A (2014). Norway spruce physiological and anatomical predisposition to dieback. Forest Ecology and Management 322: 27-36. - doi: 10.1016/j.foreco.2014.03.007

Jackson RB, Canadell J, Ehleringer JR, Mooney HA, Sala OE, Schulze ED (1996). A global analysis of root distributions for terrestrial biomes. Oecologia 108: 389-411. - doi: 10.1007/BF003337 14

Kikuta SB, Richter H (1992). A simplified pressure-volume method for the estimation of osmotic adjustement with the pressure chamber. Bodenkultur 43: 307-318. [online] URL: http:// www.researchgate.net/publication/268269163 Klemmt HJ, Taeger S, Straub C, Lemme H, Menzel A (2018). Absterbeerscheinungen der Kiefer in Mittelfranken [Pine die-off in Central Frankonia]. AFZ-Der Wald 11: 20-22. [in German]

Kunert N (2019). Das Ende der Kiefer als Hauptbaumart in Mittelfranken [The end of pine as main tree species in Central Frankonia]. AFZ Der Wald 3: 24-25. [in German]

O'Sullivan OS, Heskel MA, Reich PB, Tjoelker MG, Weerasinghe LK, Penillard A, Zhu L, Egerton JJG, Bloomfield KJ, Creek D, Bahar NHA, Griffin KL, Hurry V, Meir P, Turnbull MH, Atkin OK (2017). Thermal limits of leaf metabolism across biomes. Global Change Biology 23: 209-223. doi: $10.1111 / g c b .13477$

Stromer Von Reichenbach W (1968). 600 Jahre Nadelwaldsaat, die Leistung des Peter Stromer von Nürnberg [600 years of conifer cropping system, the achievments of Peter Stromer from Nuremberg]. In "Reichswälder bei Nürnberg - aus der Geschichte des ältesten Kunstforstes" [The imperial forests around Nuremberg - history of the oldest manmade forest] (Sperber $G$ ed). Mitteilungen aus der Staatsforstverwaltung Bayerns, München and Neustadt an der Aisch, Germany, pp. 25. [in German]

Tomczyk AM, Bednorz E (2019). Heat waves in Central Europe and tropospheric anomalies of temperature and geopotential heights. International Journal of Climatology 39: 4189-4205. doi: $10.1002 /$ joc. 6067 